\title{
Role of leukotriene antagonists and antihistamines in treatment of allergic rhinitis and asthma comorbidity
}

\author{
Alerjik rinit ve astım komorbiditesinin tedavisinde lökotriyen antagonisti ve \\ antistaminiklerin rolü \\ Ayşe Baççıoğlu', Arzu Yorgancıoğlu², Cemal Cingi', Çağlar Çuhadaroğlu \\ ${ }^{1}$ Department of Immunology and Allergy, Erzurum Region Training and Research Hospital, Erzurum, Turkey \\ ${ }^{2}$ Department of Chest Diseases, Celal Bayar University Medical Faculty, Manisa, Turkey \\ ${ }^{3}$ Department of Otorbinolaryngology, Osmangazi University Medical Faculty, Eskişehir, Turkey \\ ${ }^{4}$ Department of Chest Diseases, Acıbadem University, Istanbul Turkey
}

\begin{abstract}
Leukotriene receptor antagonists and antihistamines are efficient in reducing symptoms of allergic rhinitis and asthma when used alone or in combination. In patients with allergic rhinitis, H1-antihistamines prevent and relieve the sneezing, itching, rhinorrhea, and nasal congestion that characterize the early and the late response to allergen. H1antihistamines are not medications of choice in asthmatic patients, but controlling rhinitis will improve asthma concomitantly. Leukotriene antagonist such as montelukast may be an alternative treatment for mild persistent asthma as monotherapy where inhaled corticosteroid cannot be administered or alternative to long-acting beta agonist as an add-on therapy to ICS for moderate to severe persistent asthma. Although montelukast is an effective drug in allergic rhinitis indicated as monotherapy, but widely recommended as adjunct to antihistamine or intranasal corticosteroid. Antileukotriene agents are also widely used in the treatment of pediatric asthma. In children, maintenance treatment with inhaled corticosteroids in pure episodic (viral) wheeze was ineffective, but maintenance as well as intermittent montelukast was shown to have an efficient role in both episodic and multi trigger wheeze. Furthermore, their advantage to inhaled corticosteroids is that leukotriene receptor antagonists do not affect short-term lower leg growth rate in prepubertal children.
\end{abstract}

Key words: Leukotriene antagonist; antihistamines; allergic rhinitis; asthma.

Allergy is a reaction with inflammatory cell infiltration in the target organ which allergen has been found to cause the pathology. ${ }^{[1,2]}$ Allergens cause an immunoglobulin (Ig)

\section{Özet}

Yalnız başlarına veya kombinasyon şeklinde kullanıldıklarında lökotriyen reseptörleri ve antistaminikler alerjik rinit semptomlarını azaltmada etkilidir. Alerjik rinit hastalarında $\mathrm{H} 1$ antistaminikleri alerjene yanıtun erken ve geç dönem yanıtları olan aksırma, kaşınma, burun akması ve nazal konjestiyonu önlemekte ve geçirmektedir. Astım hastalarında H1-antistaminikleri seçilecek ilaçlar olmamalarına rağmen rinitin kontrol altına alınması aynı zamanda astımı da iyileştirecektir. Orta-ağır derecede şiddetli inatçı astımda inhale kortikosteroidin ek tedavi olarak verilemediği veya uzun etkili beta agonistin alternatif olmadığı durumlarda hafif derecede ve inatçı astımın alternatif tedavisi olarak montelukast gibi bir lökotriyen antagonistiyle monoterapi uygulanabilir. Alerjik rinitte monoterapi olarak montelukast etkili bir ilaç olmasına rağmen yaygın olarak antistamin veya intranazal kortikosteroide ek olarak önerilmektedir. Antilökotriyen ilaçlar yine pediyatrik astımın tedavisinde yaygın biçimde kullanılmaktadır. Çocuklarda kortikosteroitler inhalasyonlarıyla idame tedavisi olarak saf epizodik (viral) hışıltılı solunum (wheezing) tedavisinde etkisiz olmalarına rağmen hem devamlı hem de aralıklı olarak verilen montelukastın hem epizodik hem de birden fazla tetikleyici faktörü olan wheezingde etkili bir rolü olduğu gösterilmiştir. Ayrıca, lökotriyen reseptör antagonistlerinin prepubertal çocuklarda kısa vadede alt ekstremite gelişme hızını olumsuz etkilememesi kortikosteroit inhalasyon tedavisine göre avantajlarını oluşturmaktadır.

Anahtar sözcükler: Lökotrien antagonisti; antihistaminik: alerjik rinit; astma.

E dependent reaction characterized by an early and late phase reaction. Histamine is released after $15 \mathrm{~min}$ of exposure to allergen, whereas leukotriene is increased in the
Correspondence: Ayşe Baççı̆̆ Erzurum Region Training and Research Hospital, Erzurum, Turkey.

e-posta: aysebaccioglu@gmail.com

Received: Şubat / February 13, 2013; Accepted: Mart / March 12, 2013;

Published online: Mayis / May 4, 2013
Online available at:

www.jmedupdates.org doi:10.2399/jmu.2013001008 QR code: 
early as well as the late phase of the allergic reaction. These and other mediators lead to vasodilatation, increased permeability, and bronchoconstriction, which result to rhinitis, asthma and urticaria. ${ }^{\left[{ }^{3]}\right.}$ Allergic rhinitis has a wide range of comorbidities such as asthma, rhinosinusitis, dermatitis, and conjunctivitis. ${ }^{[4]}$

\section{The Link Between Allergic Rhinitis and Asthma}

About $70-90 \%$ of asthmatics have rhinitis, and $10-40 \%$ of rhinitics are reported to have asthma. ${ }^{[1,2]}$ Allergen-specific challenge of rhinitic patients also causes an increased response of bronchi with the presence of eosinophilia in secretions from the nose and sputum. ${ }^{[5]}$ Non-allergic diseases of the nose, such as common cold or sinusitis, can often lead to the development or worsening of asthma symptoms ${ }^{[6]}$ In conclusion, there is an increased risk that asthma will develop in patients with either allergic rhinitis or non-allergic persistent rhinitis, thus uncontrolled allergic rhinitis can lead to worsening of co-existing asthma. ${ }^{[1,6]}$ Furthermore, having comorbidity in rhinitis or asthma also impairs quality of life. ${ }^{[7]}$ Therefore a strategy should combine the treatment of upper and lower airways in terms of efficacy and safety. There are three major classes of commonly used allergicrhinitis medications-intranasal corticosteroids, antihistamines, and antileukotrienes. ${ }^{[1]}$ Combination of antihistamine and montelukast is a therapeutic option in allergic rhinitis that would benefit from successful inhibition of persistent inflammation. ${ }^{[8]}$

\section{Antihistamines}

Antihistamines downregulate allergic inflammation by interfering with histamine action at histamine-1 (H1) receptors on sensory neurons, and small blood vessels. ${ }^{[9]}$ H1-antihistamines are functionally classified into 3 groups. First generation antihistamines have poor H1 receptor selectivity, and cross the blood brain barrier, whereas second and third generation antihistamines are highly selective for the $\mathrm{H} 1$ receptor, and do not cross the blood brain barrier. ${ }^{[10]}$ Third generation antihistamines are the active enantiomer (levocetirizine) or metabolite (desloratadine and fexofenadine) derivatives of second generation drugs (cetirizine, loratadine, terfenadine). They intended to have increased efficacy with fewer adverse drug reactions.Some antihistamines, such as fexofenadine, have a strong interaction with grapefruit juice. ${ }^{[11]}$ The overall safety profiles of antihistamines such as levocetirizine and desloratadine were similar to placebo in children and adults, which had been confirmed in randomized, placebo-controlled. ${ }^{[10]}$

\section{The Role of Antihistamines in Allergic Rhinitis and Asthma}

H1-antihistamines are widely used in the treatment of allergic and nonallergic disorders. ${ }^{[1]}$ In patients with allergic rhinitis, second generation $\mathrm{H} 1$-antihistamines prevent and relieve the sneezing, itching, rhinorrhea, and nasal congestion that characterize the early and the late response to allergen. ${ }^{[10]}$ In the treatment of allergic rhinitis, oral H1antihistamines are more efficacious than chromones; but less efficacious than nasal glucocorticoids. ${ }^{[11]}$ In a study done comparing nasal H1-antihistamine and nasal glucocorticoid in patients with allergic and nonallergic rhinitis, azelastine was as effective as triamcinolone in improving nasal symptoms; sleep symptoms and quality of life. ${ }^{[12]}$

H1-antihistamines are not medications of choice in asthmatic patients. However, comorbidity of asthma and allergic rhinitis is very high (80\%) and they have clinically relevant antiasthmatic properties by controlling rhinitis. ${ }^{[13]}$ Confirming this statement, it was shown that antihistamines have reduced asthma symptoms in patients with seasonal allergic rhinitis when given alone or in combination with an antileukotriene. $^{[14]}$ The early treatment of atopic child (ETAC) study also showed that the onset of asthma was prevented by continuous antihistamine treatment. ${ }^{[15]}$ Therefore, H1-antihistamines appear to provide indirect benefit in patients with concomitant asthma and allergic rhinitis.

\section{Antileukotrienes}

Leukotriene modifiers represent the first mediator specific therapeutic option for rhinitis and asthma. ${ }^{[16]}$ Antileukotrienes are classified in two groups; cysteinyl leukotriene receptor antagonists (LTRAs) - zafirlukast, pranlukast, and montelukast - block the leukotriene receptor and thus block the end organ response of leukotriene. ${ }^{[16]}$ Zafirlukast is a leukotriene (LT) D4 receptor antagonist and is efficient in LTD4 induced bronchoconstriction, early and late responses, exercise challenge, cold induced asthma, and chronic asthma. Leukotriene synthesis inhibitors - zileuton - block the biosynthesis of cysteinyl leukotrienes. Zileuton is a 5-lipoxygenase inhibitor and is used in exercise, cold, aspirin induced bronchial hyper-responsiveness. There are also FLAP inhibitors, which are not approved by food and drug administration, but they have benefits in early and late allergic responses and cold induced asthma. ${ }^{[16]}$

Montelukast is the prevalent used antileukotriene, and is the only such agent approved for use in pediatric 
patients. ${ }^{[17]}$ It does not have any documented interactions with food, nonetheless, recently an interaction was reported that showed an increase of plasma concentration of montelukast after excessive grapefruit juice intake due to cytochrome p 450 ${ }^{[18]}$ Patient satisfaction and compliance was better with montelukast than inhaled antiinflammatory agents due to oral, and once a day administration. ${ }^{[19]}$ Furthermore, it provides a safe and effective additional antiinflammatory treatment option not only for asthma and rhinitis but also for chronic obstructive disease. ${ }^{[20]}$

\section{The Role of Antileukotrienes in Allergic Rhinitis and Asthma}

Presently, the available evidence does not support routine use of oral LTRAs in acute asthma ${ }^{[2]]}$ However, trials of intravenous treatment of LTRAs in adults and children demonstrated a reduction in the risk of hospital admission which was not quite statistically significant, and a statistically significant small increase in FEV1 was determined in the adults, but not in children. ${ }^{[19]}$

At present, antileukotrienes serve as alternative monotherapy to inhaled corticosteroids in the management of mild persistent asthma in adults and children. ${ }^{[21]}$ As monotherapy in adults and children with persistent asthma and moderate airway obstruction, inhaled corticosteroids were superior in most secondary outcomes including exacerbation requiring hospital admission, FEV1 and other lung function parameters, asthma symptoms, nocturnal awakenings, rescue medication use, symptom-free days, the quality of life, parents' and physicians' satisfaction. ${ }^{[2]}$ Furthermore, antileukotriene therapy was associated with increased risk of withdrawals due to poor asthma control and exacerbation requiring systemic corticosteroids. On the other hand, asthma control may remain suboptimal when relying on inhaled corticosteroid because of problems with compliance, poor inhaler technique and concerns about the side effects of steroids. ${ }^{[17]} \mathrm{In}$ this case, montelukast may be an alternative treatment for mild persistent asthma as monotherapy where inhaled corticosteroid cannot be administered.

Leukotriene receptor antagonists have indication as add on therapy to inhaled steroids as alternative to long acting beta2 agonists in moderate-severe persistent asthma. ${ }^{[2]}$ In comparison of long acting beta 2 agonists as an add-on therapy to inhaled corticosteroid in patients with moderate to severe persistent asthma, montelukast was found to be less efficacious and less cost-effective. ${ }^{[2]}$ However, LTRAs might decrease small airway/alveolar sites of inflammation when combined to inhaled corticosteroid therapy which was shown by a higher reduction in fractional exhaled nitric oxide levels-a marker of inflammation- in combination therapy than inhaled corticosteroid alone. ${ }^{[23]}$

Antileukotriene agents are also widely used in the treatment of pediatric asthma. In children maintenance treatment with inhaled corticosteroids in pure episodic (viral) wheeze was ineffective, but maintenance as well as intermittent montelukast was shown to have an efficient role in both episodic and multi trigger wheeze. ${ }^{[2]}$ Furthermore, their advantage to inhaled corticosteroids is that LTRAs do not affect short-term lower leg growth rate in prepubertal children. ${ }^{[25]}$

Leukotriene receptor antagonists have particular benefit for patients with exercise-induced asthma. They can be used prior to exercise to prevent exercise-induced bronchoconstriction just as short or long acting beta2 agonists. $^{[26]}$

Leukotriene receptor antagonists have beneficial effects in aspirin-sensitive rhinitis and asthma besides corticosteroids. ${ }^{[2,27]}$ Aspirin sensitivity is characterized by intense eosinophilic inflammation of nasal and bronchial tissues in non-atopic patients with chronic rhino-sinusitis and/or nasal polyps. ${ }^{[2]]}$ Montelukast reduces peripheral blood eosinophilia, but do not affect tissue eosinophilia. ${ }^{[27]}$

Corticosteroids are the mainstay of treatment in allergic rhinitis, however montelukast may be considered as an additional agent especially in treatment of patients with impaired quality of life and it may be used to reduce nasal symptom scores and to improve the disease-specific quality of life. ${ }^{[2,28,29]}$ Although montelukast is an effective drug in allergic rhinitis to decrease nasal inflammation and limit nasal congestion, sneezing, and rhinorrhea, indicated as monotherapy, but widely recommended as adjunct to antihistamine or intranasal corticosteroid. ${ }^{[11]}$ These agents primarily help with congestion and are particularly useful in asthmatics where they may have the double benefit of improving lower airway disease.

In nasal polyposis, surgery and corticosteroids is the mainstay of treatment. ${ }^{[1]}$ However, there exists an increased leukotriene production in nasal polyps, and antileukotrienes, especially montelukast, may represent a potential effective therapy. ${ }^{[30,31]}$ In a recent study it was shown that montelukast therapy might have a clinical benefit as an adjunct to nasal steroids in subjects with nasal polyposis accompanying bronchial asthma in means of rhinosinusitis disability index scores. ${ }^{[32]}$ 
Antileukotrienes are also used in allergen specific immunotherapy concomitantly to prevent local and systemic reactions. Studies showed that both antihistamines and montelukast pretreatment have been shown to reduce anaphylactic side effects when used alone which improved patients' adherence to specific immunotherapy. ${ }^{[33]}$

\section{Combination of H1-Antihistamine and Cysteinyl Leukotriene Receptor Antagonist}

Both antihistamines and antileukotrienes have been found to be useful when used alone in allergic rhinitis and asthma. Combination of both drugs showed a synergistic effect in treating seasonal allergic rhinitis. ${ }^{[3]]}$ The first combination treatment studies with montelukast was done with second generation antihistamines such as loratidine and cetirizine, followed by combinations with third generation antihistamines-fexofenadine, desloratadine, levocetirizine. Then fixed combinations of montelukast-levocetirizine and montelukast-desloratadine tablets were aiming to increase the quality of life of the patients.

\section{The Role of Combination of H1-Antihistamine and Cysteinyl Leukotriene Receptor Antagonist in Allergic Rhinitis}

It is reported that antihistamines and antileukotrienes have been found to be useful when used alone in allergic rhinitis and asthma. Combination of antihistamines and antileukotrienes showed a synergistic effect in treating seasonal allergic rhinitis. But further studies are needed for fized combinations. In a study of patients with seasonal allergic rhinitis showed that neither loratadine nor montelukast, when used on their own, conferred any benefit in terms of improving day-time nasal symptoms, while day-time nasal symptoms were significantly improved when the two drugs were combined. ${ }^{[35]}$ Similarly, montelukast plus cetirizine treatment started 6 weeks before the pollen season was effective in preventing allergic rhinitis symptoms and reduces allergic inflammation in nasal mucosa during natural allergen exposure. ${ }^{[36]}$ In persistent allergic rhinitis, montelukast, levocetirizine, desloratadine, and the montelukast/antihistamine combinations significantly improved nasal symptoms during the first 24 hours, but improvement at the end of 6 weeks was significantly greater than that achieved on the 1st day of therapy in patients treated with montelukast alone or in combination therapy with the antihistamine. ${ }^{[3]]}$ In a 32 -week randomized study, placebo, montelukast, desloratadine and levocetirizine significantly improved quality of life, but com- bining montelukast with either levocetirizine or desloratadine gave additional benefits in comparison to each agent in patients with persistent allergic rhinitis. ${ }^{[38]}$ Another study showed that, fexofenadine with montelukast combination therapy was more effective than fexofenadine alone in means of allergic rhinitis symptoms, and rhinomanometry results. ${ }^{[39]}$

Some studies reported no further benefit of combination of montelukast and antihistamine than used alone. Fexofenadine as monotherapy was shown to be equally effective as the combination of montelukast and levocetirizine in improving nasal peak flow and controlling symptoms in seasonal allergic rhinitis and asthma. ${ }^{[40]}$ Similarly, a study of patients with seasonal allergic rhinitis found that the combination of loratadine and montelukast was no more effective than montelukast alone on day-time or night-time symptoms. ${ }^{[41]}$ Furthermore, similar efficiency of monotherapy and combined therapy of antihistamine or antileukotriene was only found in patients with mild persistent rhinitis, and further studies are required to evaluate putative additivity of response with combined therapy in more severe patients.

\section{The Role of H1-Antihistamine and Cysteinyl Leukotriene Receptor Antagonist in Asthma}

In asthma, montelukast is given on regular basis to reduce eosinophilic airway inflammation. Addition of the antihistamine can amplify the early and late anti-inflammatory activities of montelukast. ${ }^{[17]}$ Combination therapy synergistically inhibits the allergen-induced early asthmatic response, and montelukast also suppresses the allergeninduced late asthmatic response. ${ }^{[17,37]}$ As a result combination of antihistamine and LTRAs has an effect that is greater than that of either drug given alone. ${ }^{[3]}$

In a randomized study of two combinations of antihistamine plus [in patients with seasonal allergic rhinitis and mild intermittent asthma, after 2 weeks cetirizine might exert more beneficial activity than desloratadine when added to montelukast as shown by the reduced nasal symptoms, inflammatory cells and cytokines in nasal lavage. In this study antileukotriene-antihistamine combinations were only effective in relieving nasal symptoms, but control of rhinitis may have a positive effect on asthma later. In a randomized study of patients with mild-tomoderate atopic asthma, after 26 hours of the treatment, early response to inhaled allergen was unchanged after desloratadine therapy and partially inhibited with montelukast therapy, whereas combination of desloratadine 
and montelukast provided superior efficacy to either blocker administered alone. ${ }^{[42]}$

Antileukotriene-antihistamine combinations when used as either monotherapy or add-on therapy to local corticosteroids have been shown to attenuate the response to adenosine monophosphate-a sensitive marker of inflammatory process in airways further reinforcing the concept of the united allergic airway. ${ }^{[43]}$ The putative benefits of such combination therapy certainly become evident when looking at concomitant effects on asthma control in patients who have concomitant allergic rhinitis.

In a multicentricrandomised double-blind crossover study comparing single-dose placebo, $5 \mathrm{mg}$ desloratadine, $10 \mathrm{mg}$ montelukast and the combination administered $2 \mathrm{~h}$ prior to allergen inhalation challenge showed that singledose co-administration of desloratadine and montelukast 2 $\mathrm{h}$ prior to allergen inhalation clinically abolished the late atopic asthmatic response in means of eosinophil recruitment and exhaled NO levels. The allergen-induced increase in sputum eosinophil numbers was significantly suppressed at $7 \mathrm{~h}$ with desloratadine and combination therapy, and at $24 \mathrm{~h}$ with montelukast and combination therapy. ${ }^{[4]]}$

In a study with patients of mild-to-moderate persistent asthmatics, treatments of montelukast + desloratadine, montelukast alone and placebo were given $10-14 \mathrm{~h}$ prior to challenge with mannitol. Both montelukast/desloratadine and montelukast compared to placebo, shortened recovery following both challenges. Montelukast was not significantly different from placebo montelukast/desloratadine combination on AHR and recovery time, highlights the relative roles of histamine in initiating the bronchoconstrictor response and cysteinylleukotrienes in sustaining it. ${ }^{[4]}$

In conclusion, antihistamines and antileukotrienes as monotherapy significantly improves nasal symptoms, with the expectation of additional benefit conferred by combination therapy.

Conflict of Interest: No conflicts declared.

\section{References}

1. Bousquet J, Schünemann HJ, Samolinski B, et al.; in collaboration with the World Health Organization Collaborating Center for Asthma and Rhinitis. Allergic rhinitis and its impact on asthma (ARIA): achievements in 10 years and future needs. J Allergy Clin Immunol 2012;130:1049-62.

2. Yorgancıŏlu A, Özdemir C, Kalaycı Ö, et al.; WHO Collaborating Center on Asthma and Rhinitis. ARIA (Allergic Rhinitis and its Impact on Asthma) achievements in 10 years and future needs. Tuberk Toraks 2012;60:92-7.
3. Canonica GW. Introduction to nasal and pulmonary allergy cascade. Allergy 2002;57:8-12.

4. Cingi C, Catli T. Phenotyping of allergic rhinitis. Curr Allergy Asthma Rep 2012;12:115-9.

5. Passalacqua G, Ciprandi G, Canonica GW. The nose-lung interaction in allergic rhinitis and asthma: united airways disease. Curr Opin Allergy Clin Immunol 2001;1:7-13.

6. Settipane G, Settipane RJ, Hagy GW. Long-term risk factors for developing asthma and allergic rhinitis: a 23-year follow-up study of college students. Allergy Proc 1994;15:21-25.

7. Kalpaklioğlu AF, Baççioğlu A. Evaluation of quality of life: impact of allergic rhinitis on asthma. J Investig Allergol Clin Immunol 2008;18:168-73.

8. Canonica GW, Compalati E. Minimal persistent inflammation in allergic rhinitis: implications for current treatment strategies. Clin Exp Immunol 2009;158:260-71.

9. O'Mahony L, Akdis M, Akdis CA. Regulation of the immune response and inflammation by histamine and histamine receptors. J Allergy ClinImmunol 2011;128(6):1153-62 .

10. Criado PR, Criado RF, Maruta CW, et al. Histamine, histamine receptors and antihistamines: new concepts. An Bras Dermatol 2010;85:195-210.

11. Kalpaklioglu F, Baccioglu A. Efficacy and safety of H1-antihistamines: an update. Antiinflamm Antiallergy Agents Med Chem 2012;11:230-7.

12. Kalpaklioglu AF, Kavut AB. Comparison of azelastine versus triamcinolone nasal spray in allergic and nonallergic rhinitis. Am J Rhinol Allergy 2010;24:29-33.

13. Yamauchi K, Shikanai T, Nakamura Y, et al. Roles of histamine in the pathogenesis of bronchial asthma and reevaluation of the clinical usefulness of antihistamines. Yakugaka Zasshi 2011;131:185-91.

14. Roquet A, Dahlén B, Kumlin M, et al. Combined antagonism of leukotrienes and histamine produces predominant inhibition of allergen-induced early and late phase airway obstruction in asthmatics. Am J Respir Crit Care Med 1997;155:1856-63.

15. Warner JO; ETAC Study Group. Early Treatment of the Atopic Child. A double-blinded, randomized, placebo-controlled trial of cetirizine in preventing the onset of asthma in children with atopic dermatitis: 18 months' treatment and 18 months' posttreatment follow-up. J Allergy Clin Immunol 2001;108:929-37.

16. Bäck M, Dahlén SE, Drazen JM, et al. International Union of Basic and Clinical Pharmacology. LXXXIV: leukotriene receptor nomenclature, distribution, and pathophysiological functions. Pharmacol Rev 2011;63(3):539-84.

17. Amlani S, Nadarajah T, McIvor RA. Montelukast for the treatment of asthma in the adult population. Expert Opin Pharmacother 2011;12:2119-28.

18. Cingi C, Toros SZ, Gürbüz MK, et al. Effect of grapefruit juice on bioavailability of montelukast. Laryngoscope 2012. doi:10.1002/lary.23700

19. Watts K, Chavasse RJ. Leukotriene receptor antagonists in addition to usual care for acute asthma in adults and children. Cochrane Database Syst Rev 2012;5:CD006100.

20. Celik P, Sakar A, Havlucu Y, et al. Short-term effects of montelukast in stable patients with moderate to severe COPD. Respir Med 2005;99:444-50 
21. Global Initiative for Asthma (GINA). Global Strategy for Asthma Management and Prevention NIH Pub. No 02-3659, January 1995. Updated December 2011.

22. Walia M, Lodha R, Kabra SK. Montelukast in pediatric asthma management. Indian J Pediatr 2006;73:275-82.

23. Fritscher LG, Rodrigues MT, Zamel N, et al. The effect of montelukast on exhaled nitric oxide of alveolar and bronchial origin in inhaled corticosteroid-treated asthma. Respir Med 2009;103:296300.

24. Bhatt JM, Smyth AR. The management of pre-school wheeze. Paediatr Respir Rev 2011;12(1):70-7.

25. Pedersen S, Agertoft L, Williams-Herman D, et al. Placebo-controlled study of montelukast and budesonide on short-term growth in prepubertal asthmatic children. Pediatr Pulmonol 2007;42:838-43.

26. Hildebrand K. Exercise-induced bronchoconstriction. Pneumonol Alergol Pol 2011;79:39-47.

27. Park HS. Aspirin-sensitive asthma: recent advances in management. BioDrugs 2000;13:29-33.

28. Pinar E, Eryigit O, Oncel S, et al. Efficacy of nasal corticosteroids alone or combined with antihistamines or montelukast in treatment of allergic rhinitis. Auris Nasus Larynx 2008;35:61-6.

29. Cingi C, Ozlugedik S. Effects of montelukast on quality of life in patients with persistent allergic rhinitis. Otolaryngol Head Neck Surg 2010;142:654-8.

30. Alobid I, Cardelús S, Picado C, et al. Antileukotrienes in rhinosinusitis and nasal polyposis. Expert Rev Clin Immunol 2008;4:331-7.

31. Cingi C, Demirbas D, Ural A. Nasal polyposis: an overview of differential diagnosis and treatment. Recent Pat Inflamm Allergy Drug Discov 2011;5:241-52.

32. Yazıcı ZM, Sayın I, Bozkurt E, et al. Effect of montelukast on quality of life in subjects with nasal polyposis accompanying bronchial asthma. Kulak Burun Bogaz Ihtis Derg 2011;21:210-4.

33. Wöhrl S, Gamper S, Hemmer W, et al. Premedication with montelukast reduces local reactions of allergen immunotherapy. Int Arch Allergy Immunol 2007;144:137-42.

34. Ciprandi G, Tosca MA, Milanese M, et al. Antihistamines added to an antileukotriene in treating seasonal allergic rhinitis: hista- mine and leukotriene antagonism. Eur Ann Allergy ClinImmunol 2004;36:67-70.

35. Meltzer EO, Malmstrom K, Lu S, et al. Concomitant montelukast and loratadine as treatment for seasonal allergic rhinitis: a randomized, placebo-controlled clinical trial. J Allergy Clin Immunol 2000;105:917-22.

36. Kurowski M, Kuna P, Górski P. Montelukast plus cetirizine in the prophylactic treatment of seasonal allergic rhinitis: influence on clinical symptoms and nasal allergic inflammation. Allergy 2004;59:280-8.

37. Ciebiada M, Ciebiada MG, Kmiecik T, et al. Quality of life in patients with persistent allergic rhinitis treated with montelukast alone or in combination with levocetirizine or desloratadine. J Investig Allergol Clin Immunol 2008;18:343-9.

38. Wilson AM, Orr LC, Coutie WJ, et al. A comparison of once daily fexofenadine versus the combination of montelukastplus loratadine on domiciliary nasal peak flow and symptoms in seasonal allergic rhinitis. Clin Exp Allergy 2002;32:126-32.

39. Cingi C, Gunhan K, Gage-White L, et al. Efficacy of leukotriene antagonists as concomitant therapy in allergic rhinitis. Laryngoscope 2010;120:1718-23.

40. Pullerits T, Praks L, Ristioja V, et al. Comparison of a nasal glucocorticoid, antileukotriene, and a combination of antileukotriene and antihistamine in the treatment of seasonal allergic rhinitis. J Allergy ClinImmunol 2002;109:949-55.

41. Wilson AM. Are antihistamines useful in managing asthma? Curr Opin Allergy Clin Immunol 2002;2:53-9.

42. Davis BE, Todd DC, Cockcroft DW. Effect of combined montelukast and desloratadine on the early asthmatic response to inhaled allergen. J Allergy ClinImmunol 2005;116:768-72.

43. Lee DK, Togias A. Systemic cross-talk between the lung and the nose. Am J Respir Crit Care Med 2001;164:726-7.

44. Davis BE, Illamperuma C, Gauvreau GM, et al. Single-dose desloratadine and montelukast and allergen-induced late airway responses. Eur Respir J 2009;33:1302-308.

45. Currie GP, Haggart K, Lee DK, et al. Effects of mediator antagonism on mannitol and adenosine monophosphate challenges. Clin Exp Allergy 2003;33:783-8.

This is an open access article distributed under the terms of the Creative Commons Attribution-NonCommercial-NoDerivs 3.0 Unported (CC BYNC-ND3.0) Licence (http://creativecommons.org/licenses/by-nc-nd/3.0/) which permits unrestricted noncommercial use, distribution, and reproduction in any medium, provided the original work is properly cited.

Please cite this article as: Baççığlu A, Yorgancioğlu A, Cingi C, Çuhadaroğlu Ç. Role of leukotriene antagonists and antihistamines in treatment of allergic rhinitis and asthma comorbidity. J Med Updates 2013;3(1):34-39. 